Type: Article

Number of Pages: 5

Language: English

\title{
THE DEVELOPMENT OF RUSSIAN CHURCH ARCHITECTURE IN THE 1990s-2017: THE STATE AND PROSPECTS
}

\author{
Ershov Bogdan Anatolievich, \\ Doctor of Historical Sciences, Professor \\ Voronezh State Technical University, Street of the 20th Anniversary of October, 84 \\ Voronezh, Russia, \\ E-mail: bogdan.ershov@yandex.ru, 8-919-243-06-34 \\ Ashmarov Igor Anatol'evich, \\ Candidate of Economic Sciences, Associate Professor of the \\ Chair of Humanitarian and Socio-Economic Disciplines, \\ Voronezh State Institute of Arts, 394053, Voronezh, st. General Lizyukov, 42, \\ Russia, E-mail: dobrinka75@mail.ru, 8-951-851-6-111
}

\author{
Danilchenko Sergey Leonidovich \\ Doctor of Historical Sciences, Professor, Academician of RAEN, \\ Russian Academy of Medical Technology, Russian \\ Academy of Natural History, Head of Research Center \\ of education development, counsel to the director at the \\ Brunch FSBEI Lomonosov Moscow State \\ University in Sevastopol. \\ E-mail: sldistorik@bk.ru
}

\begin{abstract}
The article examines church architecture in modern Russia. The historical processes of the development of church architecture are analyzed and systematized not only from the point of view of formal stylistic but also global significance. For this purpose, for the first time, a wide range of sources containing information on the sacred component of church art and on the monuments of temple architecture was studied. At the same time, many fragments of sources were first translated into English. The article uses historical and retrospective research methods that allowed to study the theoretical legacy of the modern period in the history of Russia and at the same time to generalize the place of Russian church architecture in the general context of European architectural development.
\end{abstract}

KEY WORDS: Church, Art, Priest, State, Society.

\section{INTRODUCTION}

The relevance of the research topic is explained by the complexity of the sociocultural situation in Russia as a whole. The process of restructuring that began in the 1990s led to the collapse of communist ideology, the expansion of the values of Western culture, which resulted in a decline in morality and the growth of lack of spirituality. In addition, the penetration of "new religions" into the Russian culture on the wave of democratization of society has created a clear 
threat to the disintegration of the worldview ideals and values of Russian culture, among which are traditional (religious) spiritual values.

The Russian State and the Orthodox Church have a historical experience in regulating relations with non-Orthodox Christian confessions and religious non-Christian communities, and this is especially true today, since the question of tolerance is the most controversial and problematic in today's post-Soviet Russian space [1].

In recent decades it has become customary to talk about a religious revival in our country. This statement is based on a visible increase in the number of believers, the restoration and construction of religious buildings, the growing role of religion and religious organizations in cultural and social life. However, the "religious renaissance" does not affect the deeper layers of consciousness; it covers mainly the middle and older generations [2].

The transformation of religion into a significant factor in the life of modern Russian society is accompanied by the formation in the religious sphere of a new system of contradictions that affect the entire national security system of the country, primarily its kind of spiritual security. Proceeding from this, it is assumed that the criteria for ensuring security in the religious sphere can be defined as the criteria laid down in the Article 11 of Part 5 of the Federal Law "On Freedom of Conscience and on Religious Associations".

Ensuring the national security of the Russian Federation includes also the protection of cultural, spiritual and moral heritage, historical traditions and norms of public life, the preservation of the cultural heritage of all the peoples of Russia, the formation of state policy in the field of spiritual and moral education of the population [3].

An undoubted relevance is the study of the problem of church-state relations in cultural historical retrospect and modern society. Their analysis allows you to take into account past experience, contributes to the development of an acceptable concept of the relationship between the state and the church, Orthodoxy and other religions and confessions at the present stage, the choice of ways of church-state interaction [4].

\section{METHODOLOGY}

Formation of the methodological basis of the data set is conditioned by the goal-setting attitude and is determined by the integrative nature of the culturological field of knowledge. The methods of comparative-historical, historical-typological, structural-systemic and semiotic methods are applied in the work [5].

Comparative and historical-typological procedures in the analysis of facts on a long stretch of historical time made it possible to reveal patterns in the relationship between the state, government, society and the church as a spiritual institution, as well as those general trends that determine their specifics.

It is important for us to move on to the characteristics of the religious picture of the world and the place in it of a person, the system of values and ritual practice with regard to the nonOrthodox church (culture) and new faiths [6].

The methods of the structural-system method allowed us to consider the structure of the church as a relatively stable set of relations of elements.

\section{RESULTS}

At any stage of development, the dynamics of state-church relations in Russia is determined by socio-political and cultural-historical conditions. The relations between such institutions as the State and the Church are in interaction with the changes of the political system of the country.

After the victory of the 1917 revolution, an attempt was made by the state to substitute Orthodox spirituality, which was determined by the core of Russian culture, communist 
ideology. Proclaiming a secular society, the communist ideologues imposed by new values on the Russian people that orient people to build a new society in which there is no place for religion. Secularization, in fact, it implies the advancement of the worldly values as well as in the spiritual life of Russia. In the destruction of spiritual traditions in the life of Russian society, the threat of the existence of all.

The assertion of the values of secular culture led to the emergence of a different form of ecclesiastical relations, expressed in the principle of the separation of church and state, legislatively enshrined in the constitutions. This meant that the Orthodox religion was ceased to be state ideology, instead of an anti-religious ideology was asserted. A distinctive feature of this form of ecclesiastical relations was that, while declaring its non-interference in the affairs of the church, the state at the same time limited its role in society, making it dependent on the ideology that it (the state) conducts [7].

Soviet power, pursuing certain ideological goals - to end religion as an obsolete and hostile to the new order of the worldview, continued its offensive against the church. Closed and defeated temples, priests and representatives of the higher clergy were both exiled or shot. Church services were limited, religious processions and religious holidays were banned.

At the same time, new public organizations were created.

The situation changed dramatically with the outbreak of World War II. From the very first days of its existence, the Church was issued a condemnation of fascism and was called on to collect money for the motherland. The patriotic position of the clergy and believers served as the basis for the warming of relations between the state and the Church. The church of the church was tested to its spirituality. During the war, the Church came out of the position of solidarity, consolidation of the society, based on patriotism, the heroic experience, and the rich spiritual traditions of the people. In the face of the threat of the destruction of the Soviet Union, Stalin's government turned to the church as an organization capable of rallying the people, raising and consolidating its spirit, and the church, its strength, ability and devotion to the state. It was not disappeared, moreover, it is still great [8].

In 1945, the Council of People's Commissars of the Soviet Union granted religious organizations the rights of the church in the interests of leasing, building, purchase of houses, transport and utensils for church needs. In the Soviet press, anti-religious propaganda practically ceased. Although slowly, but the buildings selected by the authorities for churches began to return, they began to be equipped with utensils necessary for canonical services.

However, from the mid-1950s onwards, the cases of administration became regular. This was facilitated by the fact that most foreign religious organizations were involved in a "cold war" against the USSR. In many countries, the activity of clerical parties has become more active. Clergy, an insult to the feelings of believers, replaced systematic and in-depth propaganda of scientific, atheistic views. Throughout the post-war period, the state, declaring its loyalty to the church on the world stage, did not stop the offensive on its rights.

In the 1960s, with the coming to power of Khrushchev, relations between the state and the church began to decline. Decisions and decrees on strengthening atheistic propaganda are the result of adoption and active policy of the Soviet power [9].

The main feature of this period is the desire of the authorities to establish complete control over all manifestations of church life. Anti-religious work was recognized as the main lever in the formation of a scientific-materialistic worldview. The construction of a "society without religion"

When L.I. Brezhnev came to power, an anti-religious campaign ceased in the country, the closure of churches and monasteries ceased, but atheist propaganda did not stop among the population.

In general, until the late 1980s, the state, observing the demand for struggle against religion, implemented it in various forms of atheistic propaganda, accompanied by increased oppression of the church, control of its activities and even interference in internal church affairs. 
The desire to root out the Faith during the years of Soviet power has led to a catastrophic mental and spiritual weakening of subsequent generations [10].

The process of restructuring, which began in the 1990s, led to the collapse of communist ideology, and the expansion of the values of Western culture led to a drop in morality and an increase in the lack of spirituality of a particular part of the youth. The religious revival in postSoviet Russia was associated with the destruction of the ideals and value system of the Soviet period. In addition, the process of the penetration of "new religions" into Russian culture on the wave of democratization of society created a clear threat of the breakdown of the ideological ideals and values of Russian culture [11].

The current situation contributed to the crisis of humanism, which gave rise to a feeling of pessimism, hopelessness of life, psychological sensations of the fragility of the surrounding world in the population of Russia [12].

In a very short period of time, a single state that largely defined the geopolitical picture of the world disappeared, the state structure, institutions of power and its attributes changed radically, the process of forming a new legal order and state ideology began, and the system of priorities and values collapsed. In the context of the spiritual and moral crisis, the need was recognized to return Russia to national identity. In these conditions, the authorities realized the need to form a new system of values that requires certain spiritual guidelines, in which quality the values of Orthodox culture could perform.

\section{DISCUSSION}

In modern Russia, the scientific interest of researchers to the problems of religion, the attitude of society towards it, and the process of revival of Orthodox traditions has greatly increased. The problems of church and state relations in the cultural and historical retrospective and at the present stage of the development of society are now devoted to a sufficient number of works of researchers. Among them, it should be noted the work of scientists such as V.A. Alekseeva, S.A. Gvozdeva, V.A. Kuroyedov, S.S. Levoshko, M.I. Odintsov, V.I. Kupriyanova and others.

An analysis of the cultural and historical situation that had developed in Russia from the point of view of relations between state structures and the church contains the works of L.V. Dragunova, S.M. Dudaryonok, V.I. Kupriyanova, M.B. Serdyuk and others.

A process of globalization that threatens the loss of national and spiritual identity accompanies the process of reviving the traditions of Orthodox culture in Russia. These problems are developed in the writings of scientists such as Yu.Yu. Bulycheva, A.L. Kazina, A.I. Kugaya, A.P. Serova, N.K. Simakova, A.N. Shvechikova and others.

Among them, we want to highlight the work of A.I. Kuga "Orthodoxy and SelfIdentification of Russia in the XXI Century." In this paper the process of loss of identity is considered, since in recent years values alien to Russian culture, including spiritual ones, have been imposed. According to A.I. Kuga, the essence of the spiritual crisis that engulfed modern Russia, is the loss of supra-individual values [13].

The historical experience of Orthodoxy in the field of architecture largely determines the semantic and artistic content of the temple architecture at the present stage. The history of the formation of Russian temple architecture is connected with the cultural and historical development of Russia [14].

In the analysis of the specifics of modern temple construction, the work took into account the works of such authors as M.V. Alpatov, G. Arnheim, A.V. Bunin, V.L. Glazychev, N.F. Gulyanitsky, A.E. Gutnov, A.V. Ikonnikov, G.I. Iskrzytsky, T.D. Kilpe, N.P. Kradin, A.A. Lazarev, A.G. Lazarev, F.A. Novikov, V.I. Pilyavsky, P.A. Rappoport, T.Savarenskaya, I.S. Serov, Yu.S. Ushakov, etc. 
An appeal to literature on urban planning and temple construction is because the authors of the projects of modern churches, irrespective of the time and place of their construction, use traditional methods and follow the Orthodox canons in their work [15].

\section{CONCLUSION}

At present, we can observe the revival of Orthodox culture, which is also taking place at the level of traditional forms of religious activity. Such traditional forms include enlightenment, patriotic education, charity and missionary activity. Russian citizens, various organizations, enterprises make donations for the construction or improvement of churches [16].

The temple in the modern socio-cultural situation becomes a structural centre of the formation of Orthodox culture. There is not only the restoration of destroyed churches, but also new ones are being built, the traditional mission of the church is being restored as a key factor in the socio-cultural stability and unification of Russians around the priorities of morality, justice, peace-making. The Church begins to play not only culture-forming, but also state-forming role in the life of modern Russian society [17].

\section{REFERENCES}

65.

Bertash A. B., Priest. About modern Church building in St. Petersburg Kapitel. №. 2 (6). 2009. P. 58-

Ershov B. A., Ashmarov A. I., Drobyshev V. A., Zhdanova TA, Buravlev A. I. In the collection: The European Proceedings of Social and Behavioral Sciences 2017. P. 324-331.

Ershov B. A., Fursov V. N. History of development of missionary service of the Russian Orthodox Church // Questions of history. 2017. №. 6. P. 165-172.

Ershov, B. A. Russian Orthodox Church in the structure of public administration in the XIX - early XX centures. [Text]: [monograph] Voronezh, V: FGBOU VPO " Voronezh State Technical University" 2013

Gubareva O. V. Canonical art of the Church in the modern architectural ensemble (chapel of the Nativity in the business center of the NGO "Rubin") Academy of Arts and Orthodox Church. Collection of scientific. articles'. SPb., 2004. P. 46-51.

Khalpakhchyan, O. H. the Principles of addition religious ensembles of Armenia Architectural legacy. Vol. 24. 1976. P. 116-133.

Kirikov B.M. Church of the Resurrection (to the history of the" Russian style " in St. Petersburg) Nevsky archive: Historical collection. M. SPb., Atheneum: Phoenix. 1993. P. 204 - 245.

Krichinsky S. S. Temple in memory of the 300th anniversary of the Romanov house Architect. 1914. №. 11. P. 122-123.

Kudryavtsev M. P., Kudryavtseva T. N. Russian Orthodox Church. Symbolic language of architectural forms to light. 1995. №. 17. P. 65-87.

Kurbatov V. about Russian style for modern buildings Zodchiy. 1910. №. 30. P. 310 -312.

Kuzmina I. B. Ancient temples: the problem of creating modern Church interior Bulletin of young scientists. Cultural studies and art history 1'06. №. 3. 2006. C. 70-76.

Laytar N. In. The problem of style in modern temple architecture in Russia. Izvestiya Rossiyskogo Gosudarstvennogo Pedagogicheskogo Universiteta imeni A. I. Herzen. №. 36 (77): Scientific journal. - SPb., 2008. P. 120-126.

Orlovsky V. on the design of churches in modern conditions Architecture. Construction. Design. 2003. №. 6 (40). P. 50-53.

Perevozchikova, L. S. ,Ershov, B. A., Ashmarov, I. A., Volkova, E. A. Role of the Russian Orthodox Church in the Life of Peoples in Russia in the XIX. The Beginning of The XX-th Centuries. Bylye Gody, 43 2017. (1), P. 121-128. 72-82.

Punin A. L. at the origins of a new style Problems of development of Russian art. Vol. IV. L., 1972. P.

Puppies A. C. on the traditional form in modern Church building Christian architecture: New materials and research. M., editorial URSS, 2004. P. 861-867.

Tikhon (Novels), Archimandrite. Consecration of the Church Journal of the Moscow Patriarchate. 2003. №. 8. P. 61-63.

Zavarikhin S. P. on the verge of design Tri iskusstva. Saint-Petersburg. 2003. №. 6. P. $22-27$.

Zhilkina M. Celebration of the feast day of St. Petersburg Journal of the Moscow Patriarchate. 2001. №. 10. P. 42-53. 